\title{
PENGARUH ONLINE SHOP DAN KELOMPOK TEMAN SEBAYA TERHADAP PERILAKU KONSUMTIF MAHASISWA PENDIDIKAN EKONOMI ANGKATAN 2017 UNIVERSITAS NEGERI MEDAN
}

\author{
Noni Rozaini ${ }^{1 *}$, Hindun Neni Sari ${ }^{1)}$ \\ ${ }^{1)}$ Fakultas Ekonomi Universitas Negeri Medan \\ *Penulis Korespondensi: nonirozaini@gmail.com
}

\begin{abstract}
Penelitian ini bertujuan untuk mengetahui pengaruh online shop dan kelompok teman sebaya terhadap perilaku konsumtif mahasiswa pendidikan ekonomi angkatan 2017 universitas negeri medan. Penelitian ini dilaksanakan di fakultas ekonomi universitas negeri medan T.P 2019/2020. Populasi dalam penelitian ini adalah seluruh mahasiswa pendidikan ekonomi angkatan 2017 yang berjumlah 113 mahasiswa dan sampel dalam penelitian ini yaitu 88 mahasiswa dengan teknik pengambilan sampel yaitu acak. Teknik dalam pengumpulan data dalam penelitian ini menggunakan angket. Hasil analisis berganda diperoleh persamaan $Y=6,088+0,246 X 1+0,666 X_{2}$. Selanjutnya koefesien determinasi $\left(R^{2}\right) 0,607$ yang artinya adalah sebesar $60,7 \%$ variabel X1 dan X2 dapat menjelaskan perilaku konsumtif mahasiswa (Y) dan sisanya sebesar 39,3\% dijelaskan oleh variabel lainnya yang tidak dikaji dalam penelitian ini. berdasarkan uji $t$ diperoleh bahwa masing-masing variabel X1 terdapat pengaruh positif dan signifikan terhadap perilaku konsumtif mahasiswa dengan nilai thitung $>$ ttabel $(3,835>1,662)$ dan ada pengaruh positif dan signifikan variabel kelompok teman sebaya terhadap perilaku konsumtif dengan nilai thitung>ttabel $(10,544>1,662$. Sedangkan uji f diperoleh hasil bahwa ada pengaruh positif dan signifikan online shop dan kelompok teman sebaya terhadap perilaku konsumtif mahasiswa dengan nilai fhitung $>$ ftabel $(65,708>3,10)$ dan nilai signifikansi sebesar $\alpha(0,00<0,05)$
\end{abstract}

Keywords: Online Shop, Kelompok Teman Sebaya, Perilaku Konsumtif 


\section{PENDAHULUAN}

Dewasa ini berbagai macam produk ditawarkan kepada konsumen. Produk-produk tersebut bukan hanya barang yang dapat memenuhi kebutuhan konsumen, tetapi juga produk yang dapat memuaskan keinginan konsumen. Kebutuhan dan keinginan yang tidak terbatas mampu membuat manusia mengkonsumsi kebutuhan dan keinginannya secara berlebihan. Sehingga ini mampu mendorong seseorang untuk mengkonsumsi suatu barang secara terus menerus yang cenderung meningkat. Maka secara tidak langsung akan membentuk kecenderungan berperilaku konsumtif pada seseorang.

Menurut Taryadi (2007)Perilaku konsumtif dalam pandangan ekonomi adalah gaya hidup yang lebih mengutamakan keinginan untuk mengkonsumsi suatu barang atau jasa secara berlebihan. Sifat ini cenderung mengabaikan faktor pendapatan maupun ketersediaan sumber daya ekonomi seseorang dalam melakukan tindakan konsumsi.

Kotler dan Keller (2012: 166)

menyatakan bahwa "faktor yang mempengaruhi keputusan pembelian yaitu faktor internal (persepsi, keluarga, motivasi, pengetahuan, sikap, dan pembelajaran, kelompok usia, dan gaya hidup), faktor eksternal budaya, kelas sosial, keanggotaan suatu kelompok dan faktor situasional. Adapun situasional pada masa sekarang ini adalah maraknya teknologi yang mengakibatkan perbelanjaan online meningkat.

Selain itu perilaku konsumtif mahasiswa di tandai dengan gaya berpakaian, alat kosmetik, tas dan sepatu yang dipakai mahasiswa tekadang melebihi kebutuhan mereka. Apalagi saat ini cara berbelanja sangat dipermudah dengan adanya internet. Seseorang tidak perlu keluar rumah untuk mengelilingi toko pakaian untuk mencari baju yang diinginkan, akan tetapi cukup melihat di internet.

Teknologi yang semakin canggih ini membuat perilaku konsumtif mahasiswa semakin meningkat. Seperti aplikasi instagram, facebook, whats app dan lainlainnya yang semakin marak yang hampir semua menggunakannya. Dalam aplikasi ini juga produsen menawarkan berbagai macam item barang yang mengikuti zaman. Dan juga yang menarik perhatian konsumen adalah harga yang ditawarkan relatif lebih murah.
Selain maraknya penggunaan aplikasi instagram, facebook, dan lain-lain yang mampu mempengaruhi perilaku konsumtif mahasiswa yaitu kelompok teman sebaya. Kelompok teman sebaya adalah teman sebaya merupakan sekumpulan dua orang atau lebih yang memiliki usia yang hampir sama, status sosial, serta kebutuhan yang relative sama dengan melakukan interaksi intensif dan teratur sehingga mampu menciptakan pengaruh yang positif maupun negatif. Yusuf (2012: 60) mengemukakan bahwa "teman sebaya lebih memberikan pengaruh dalam memilih: cara berpakaian, hobi, perkumpulan (club), dan kegiatan-kegiatan sosial lainnya."

Berdasarkan observasi awal yang dilakukan di fakultas ekonomi pada mahasiswa pendidikan ekonomi angkatan 2017, diperoleh hasil bahwa banyak mahasiswa yang mengkases online shop pada media sosial instagram yang dilihat pada gambar 1.1 dibawah ini.

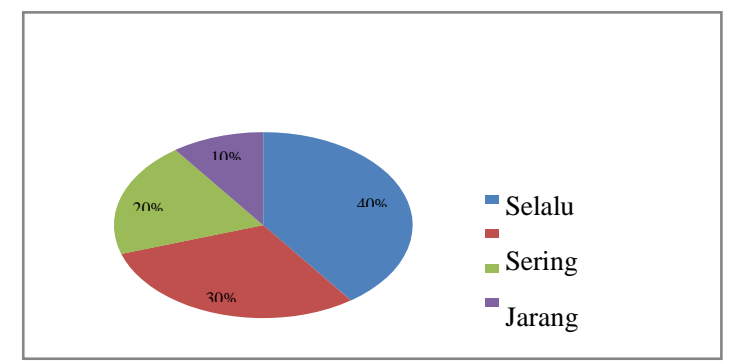

\section{Sumber: Data di olah \\ Gambar 1 Persentase Frekuensi Terkena Terpaan Onlineshop}

Berdasarkan hasil observasi yang dilakukan penulis pada gambar di atas dapat diketahui bahwa $40 \%$ atau sebanyak 16 dari 40 orang yang selalu mengakses online shop pada media sosial instagram, dan terdapat $25 \%$ atau 10 dari 40 orang yang jarang mengakses online shop pada media sosial instagram. Alasan mengapa instagram diminati oleh kaum remaja adalah karena aplikasi ini bukan hanya untuk berinteraksi dan berkomunikasi bagi penggunanya tetapi juga digunakan remaja untuk meng-explore apa yang sedang trend di kalangan artis ataupun selebgram yang diidolainya.

Selain data online shop di instagram di atas, yang menjadi pertimbangan awal dalam penelitian ini adalah kelompok teman sebaya. Sebab teman sebaya lebih memberikan pengaruh dalam memilih: cara berpakaian, hobi, perkumpulan (club), dan kegiatan- 
kegiatan sosial lainnya." Karena terkadang remaja membeli sesuatu bukan karena kebutuhan tapi karena pendapat orang lain sangat penting bagi dirinya dan ia ingin tampil menarik seperti teman-temannya. Yusuf (2012: 60). Adapun data keinginan meniru produk yang dikenakan teman sebaya diperoleh sebagai berikut :

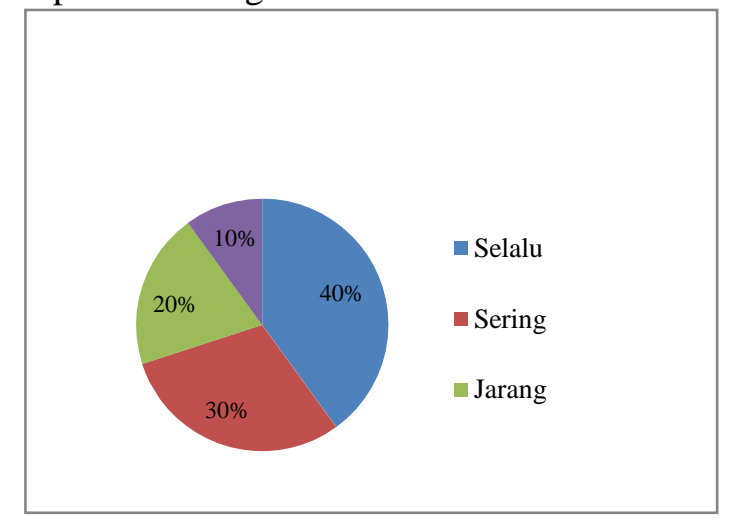

Sumber: Data diolah

\section{Gambar 2 Persentase Frekuensi keinginan Meniru Produk Bary}

Berdasarkan data yang disajikan pada diagram diatas dapat diketahui bahwa $40 \%$ atau sebanyak 16 orang yang berkeinginan meniru produk terbaru yang dikenakan oleh temannya dan terdapat $10 \%$ atau 4 orang yang tidak pernah berkeinginan meniru produk yang dikenakan oleh temannya.

Dari hasil penelitian awal yang dilakukan penulis mengenai perilaku konsumtif mahasiswa pendidikan ekonomi angkatan 2017 Universitas Negeri Medan dapat disimpulkan bahwa perilaku konsumtif mahasiswa tersebut tergolong tinggi. Hal ini dapat dilihat dari pertanyaan yang di ajukan kepada responden, pertama sebanyak $70 \%$ responden menjawab selalu tertarik membeli suatu barang ketika ditawarkan promo atau diskon, kedua adanya mahasiswa yang membeli suatu barang karena maraknya online shop di instagram sebanyak $40 \%$ yang menjawab selalu, ketiga membeli barang dikarenakan ingin meniru teman sebaya sebanyak $40 \%$ yang menjawab selalu dan $30 \%$ menjawab sering.

\section{TINJAUAN TEORITIS}

\section{Pengertian Perilaku Konsumtif}

Perilaku konsumtif merupakan Perilaku seseorang yang tidak lagi berdasarkan pertimbangan yang rasional, kecendrungan matrealistik, hasrat yang besar untuk memiliki benda - benda mewah dan penggunaan segala hal yang dianggap paling mahal yang didorong oleh semua keinginan untuk memenuhi hasrat kesenangan sematamata. Wahyudi (dalam Kanserina, 2015.

Noni mengatakan bahwa perilaku konsumtif mahasiswa dapat ditandai dengan gaya berpakaian, alat kosmetik, tas dan sepatu yang dipakai mahasiswa terkadang melebihi dari kebutuhan mereka sendiri. Setiap mode fashion yang trend tidak pernah ketinggalan. Apalagi saat ini cara berbelanja saat ini sangat mudah dengan adanya internet. Seseorang tidak perlu keluar rumah untuk mengelilingi toko pakaian untuk mencari baju yang diinginkan, akan tetapi cukup melihat di internet dengan mendownload aplikasi misalnya, shopee, OLX, buka lapak dan aplikasi lainnya.

Masuknya perilaku konsumtif tersebut membawa perubahan gaya yang amat jelas pada mahasiswa. Perilaku konsumtif mahasiswa yang mulai terbiasa, semakin lama menjadi suatu kebiasaan sebagai gaya hidup. Akibatnya, membawa mahasiswa kedalam dunia yang lebih memperhatikan penampilan mereka, harga diri, serta cara mengikuti perkembangan dilingkungannya. Hal tersebut membuat mahasiswa sulit untuk bersikap rasional, yang pada mulanya diharapkan mampu untuk bersikap rasional atas segala perkembangan yang terjadi.

\section{Ciri-ciri Perilaku Konsumtif}

Adapun ciri-ciri perilaku konsumtif menurut Sumartono (2012) adalah seabagai berikut :

1. Membeli karena penawaran hadiah yang menarik.

2. Membeli barangnya karena menarik.

3. Membeli barang karena menjaga penampilan diri dan gengsi.

4. Membeli barang karena program potongan harga.

5. Kecenderungan membeli barang yang dianggap dapat menjaga status sosial.

6. Memakai sebuah barang karena pengaruh model yang mengiklankan barang.

7. Penilaian bahwa pembeli barang dengan harga mahal akan menimbulkan rasa percaya diri yang tinggi.

8. Membeli lebih dari dua barang sejenis dengan merk yang berbeda. 


\section{Online Shop}

\section{Pengertian Online Shop}

Online shop adalah sebuah wadah yang melakukan penjualan atau pembelian terhadap barang atau jasa tanpa bertatap wajah secara langsung dengan menggunakan media sosial ataupun web browser. Menurut Sari (2015:208) Online Shop atau belanja via internet adalah suatu proses pembelian barang atau jasa dari mereka yang menjual melalui internet, atau layanan jual beli secara online tanpa harus bertatap muka dengan penjual atau pembeli secara langsung. Online Shop bukan hanya sekedar dianggap sebagai pemilihan dalam berbelanja. Melainkan telah menjadi bagian dari adanya perubahan sosial budaya dalam masyarakat.

\section{Online Shop di Instagram}

Online shop atau belanja online merupakan pembelian barang atau jasa dengan melalui internet. Kemudian online adalah suatu keadaan dimana seseorang terhubung dengan jaringan. Melalui online shop, konsumen dapat melihat barang-barang yang dijual melalui gambar atau foto-foto bahkan video. Online shop telah banyak di Instagram searah dengan semakin berkembangnya bisnis dan meningkatnya kebutuhan masyarakat. Barang-barang yang dijual hampir semua ada di Instagram seperti pakaian, aksesoris, tas, buku, sepatu, kosmetik, mainan anak, alat olahraga, makanan ringan, hingga alat elektronik dapat dijajakan dalam situs jejaring sosial tersebut.

Maraknya online shop yang bermunculan di Instagram juga merupakan hasil dari maraknya fashion terkini yang tengah menggandrungi masyarakat. Online shop baru di instagram biasanya menggunakan jasa endorsment untuk mengenalkan akunnya pada masyarakat luas. Biasanya yang menjadi sasaran endorsment para online shop ini adalah para artis yang sudah memiliki banyak followers.

Online shop di instagram muncul dengan harga yang cukup bersaing. Bersaing dengan harga di toko pada umumnya maupun online shop lainnya. Online shop di instagram berlomba-lomba menawarkan harga yang lebih murah. Berbagai strategi juga dilakukan demi memperoleh followers yang banyak dan juga pelanggan baru. Salah satunya seperti membebaskan biaya pengiriman atau promosi seperti apabila membeli produk yang banyak akan diberi potongan harga. Ditambah lagi dengan proses pembelian yang ditawarkan juga tidak sulit. Cukup dengan memilih gambar yang tersedia di akun instagram tersebut, memesannya kemudian membayar dengan transfer langsung. Hal ini sangat mudah dilakukan terutama bagi mahasiswa. Inilah yang menjadi daya tarik instagram selain dari berbagai foto sehingga dengan berbagai kemudahan yang ditawarkan mengakibatkan pembelian secara terus menerus dan menjadi perilaku konsmtif.

\section{Pengertian Kelompok Teman Sebaya}

Kelompok tema sebaya adalah teman sebaya (seumuran) merupakan sekumpulan dua orang atau lebih yang memiliki usia yang hampir sama, status sosial, serta kebutuhan yang relative sama dengan melakukan interaksi intensif dan teratur sehingga mampu menciptakan pengaruh yang positif maupun negatif.

Novandi dan Djazari (2011:6), mengungkapkan bahwa "teman sebaya adalah suatu lingkungan yang terdiri dari sekelompok orang yang mempunyai kesamaan sosial, seperti kesamaan tingkat dengan berbagai karakter individu yang mampu mempengaruhi perilaku individu.

\section{Pengaruh Teman Sebaya}

Pergaulan terhadap teman sebaya dapat mempengaruhi perilaku. Pengaruh tersebut dapat berupa pengaruh positif maupun negatif. Pengaruh positif yang dimaksud adalah ketika teman sebaya membawa kita kedalam aktivitas yang bermanfaat seperti menabung. Sedangkan pengaruh negatif yang dimaksud yaitu berupa kehidupan yang mewah serta membeli sesuatu tanpa manfaat yang dihasilkan dari barang tersebut.

\section{Fungsi Teman Sebaya}

Menurut Slamet Santoso (2009 : 79), mengatakan bahwa ada delapan fungsi pertemanan yaitu mengajarkan kebudayaan, mengajarkan mobilitas sosial, membantu peranan sosial, sumber informasi, saling ketergantungan, mengajarkan moral, kebebasan berpendapat, dan organisasi baru.

Pada prinsipnya hubungan lingkungan teman sebaya mempunyai arti yang sangat penting bagi remaja (Piaget dan Sullivan) dalam (Desmita, 2014:230) menekankan bahwa melalui interaksi dengan teman sebaya 
anak- anak dan remaja mempelajari modus relasi yang timbal balik secara simetris "anak mempelajari prinsip-prinsip kejujuran dan keadilan melalui peristiwa pertentangan dengan teman sebayanya". Remaja memiliki kebutuhan yang kuat untuk disukai dan diterima kawan sebaya atau kelompok. Sebagai akibatnya mereka akan merasa senang apabila diterima dan merasa tertekan apabila dikeluarkan dan diremehkan oleh kawan sebayanya.

\section{METODE PENELITIAN}

Penelitian dilakukan di Fakultas Ekonomi Universitas Negeri Medan yang beralamat di Jalan Willem Iskandar, Pasar V Medan Estate yang dilaksanakan pada bulan februari atau pada semester genap tahun ajaran 2019/2020 yang berjumlah 113 mahasiswa dan responden sebanyak 88 mahasiswa menggunakan simple random sampling. Teknik pengumpulan data pada penelitian ini observasi dan kuesioner/angket. Kemudian melakukan uji asumsi klasik yaitu uji normalitas dan linearitas dan teknik analisis data dengan menggunakan analisis regresi berganda yang sebelumnya sudah dilakukan uji instrumen penelitian.

\section{HASIL DAN PEMBAHASAN Uji Instrumen \\ Penelitian Uji Validitas}

Dari hasil uji validitas menggunakan IBM SPSS 20, mendapatkan 25 item pernyataan yang valid untuk variabel perilaku konsumtif, 23 pernyataan valid untuk variabel online shop dan 2 item tidak valid karena nilai $\mathrm{r}_{\text {hitung }}<\mathrm{r}_{\text {tabel }}$ atau sig $>0,05$. Untuk variabel $\mathrm{X} 2$ mendapat 22 pernyataan valid dan 3 item pernyataan tidak valid karena nilai $\mathrm{r}_{\text {hitung }}<\mathrm{r}_{\text {tabel }}$ atau sig $>0,05$.

\section{Uji Reliabilitas}

Untuk reliabel kuesioner digunakan Cronbach Alpha dari item yang valid. Perilaku konsumtif mahasiswa (Y) menunjukkan bahwa reliabel untuk digunakan karena $r_{\text {hitung }}>r_{\text {tabel }}$ $(0,904>0,361)$, Online Shop menunjukkan bahwa kuesioner reliabel untuk digunakan karena rhitung>rtabel $(0,841>0,361)$. Kelompok teman sebaya menunjukan bahwa kuesioner reliabel untuk digunakan karena rhitung > rtabel $(0,927>0,361)$.

\section{Uji Asumsi Klasik}

Dari hasil uji normalitas menggunakan SPSS di dapat nilai signifikansi sebesar 0,825 hal ini berarti $0,825>0,05$ sehingga data dapat dikatakan data berdistribusi normal.

\section{Uji Linearitas}

Berdasarkan hasil uji SPSS dapat diketahui bahwa terdapat linearitas antara variabel Online Shop (X1) terhadap Perilaku Konsumtif Mahasiswa (Y) begitu juga antara variabel Kelompok Teman Sebaya (X2) terhadap Perilaku Konsumtif Mahasiswa (Y). Hal ini masing masing diperlihatkan dengan nilai signifikansi pada deviation from linearity sebesar 0,182 nilai tersebut $>0,05$ dan 0,3186 nilai tersebut $>0,05$.

\section{Uji Multikolinearitas}

Berdasarkan hasil SPSS didapat bahwa nilai tolerance kedua variabel bebas baik Online Shop dan Kelompok Teman Sebaya adalah sebesar 0,996 berarti $>0,10$. Nilai VIF antara kedua variabel bebas Onlien Shop (X1) dan Kelompok Teman Sebaya (X2) sebesar 1,004 berarti < 10. Hal ini menunjukkan bahwa di dalam model regresi tidak terjadi multikolinearitas.

\section{Teknik Analisis Data}

\section{a. Analisis Regresi Linear Berganda}

Setelah uji asumsi klasik dipenuhi, maka dilakukan perhitungan analisis regresi linier berganda. Diperolehhasilsebagaiberikut:

Tabel 1

Hasil Uji Regresi Linear Berganda

\begin{tabular}{|c|c|c|c|c|c|}
\hline \multirow[b]{2}{*}{ Mod e 1} & \multicolumn{2}{|c|}{ Unstandardized Coefficients } & \multirow{2}{*}{$\begin{array}{r}\text { Standardiced Coefficients } \\
\text { B e t a }\end{array}$} & \multirow[b]{2}{*}{$\mathrm{T}$} & \multirow[b]{2}{*}{ Sig. } \\
\hline & B & Std. Error & & & \\
\hline 1 (Constant) & 6,088 & 5,869 & & 1,037 &, 302 \\
\hline online shop &, 246 &, 064 &, 261 & 3,835 & , 000 \\
\hline kelompok teman sebaya &, 666 &, 063 &, 718 & 10,544 & ,000 \\
\hline
\end{tabular}

$Y=6,088+0,246 X_{1}+0,666 X_{2}$

Dari persamaan tersebut dapat dijelaskan :

1. Konstanta sebesar 6,088 dapat diartikan bahwaPerilaku konsumtif mahasiswa (Y) akan bernilai 6,088 dimana Online Shop (X1) dan Kelompok Teman Sebaya(X2) sebesar nol.

2. Koefesien regresi online shop (X1) bernilai 0,246 menyatakan bahwa kenaikan online shop sebesar satu satuan akan meningkatkan perilaku 
konsumtif sebesar 0,246. (asumsi faktor lain konstan).

3. Koefesien regresi kelompok teman sebaya (X2) bernilai 0,666 menyatakan bahwa kenaikan kelompok teman sebaya sebesar satu satuan akan meningkatkan perilaku konsumtif sebesar 0,666 (asumsi faktor lain konstan).

\section{b. Uji Hipotesis Secara Parsial \\ Hasil Uji Hipotesis Secara Parsial (Uji t) \\ Tabel 2 Hasil Uji Hipotesi Secara Parsial (Uji t)}

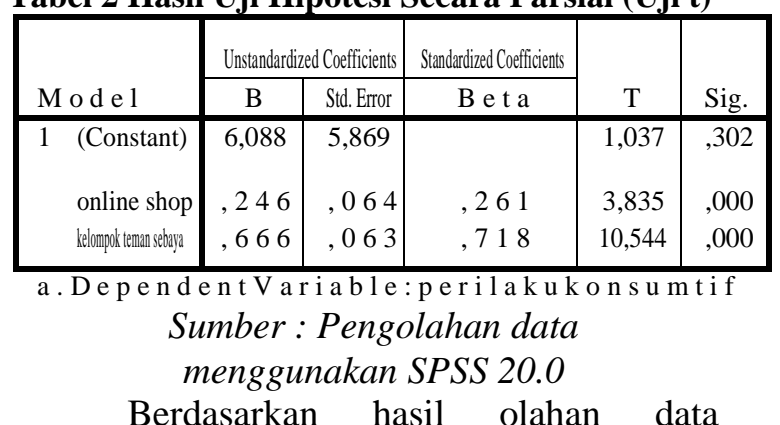

diketahui bahwa nilai thitung pada variabel online shop sebesar 3,835 dan nilai signifikansi 0,000. Hal ini menunjukkan bahwa $t_{\text {hitung }}>t_{\text {tabel }}(3,835>1,662)$ dan nilai signifikansi $\alpha(0,00<0,05$ yang berarti dapat disimpulkan bahwa hipotesis pertama diterima $\left(\mathrm{Ha}_{1}\right)$ yaitu ada pengaruh positif dan signifikan antara online shop terhadap perilaku konsumtif mahasiswa pendidikan ekonomi angkatan 2017 Universitas Negeri Medan.

\section{c. Uji Hipotesis Secara Simultan Hasil Uji Hipotesis Secara Simultan (Uji F) Tabel 3}

Hasil Uji Hipotesis Secara Simultan (Uji F)

\begin{tabular}{|c|c|c|c|c|c|}
\hline Mode 1 & Sum of Squares & D f & Mean Square & $\mathrm{F}$ & S ig \\
\hline \multirow{3}{*}{$\begin{array}{r}\text { Regression } \\
\text { Residual } \\
\text { T o t a } 1 \\
\end{array}$} & 3030,996 & 2 & 1515,498 & 65,708 &, $000^{\mathrm{b}}$ \\
\hline & 1960,459 & 85 & 23,064 & & \\
\hline & 4991,455 & 87 & & & \\
\hline $\begin{array}{l}\text { a. De } \\
\text { if } \\
\text { b. Pred } \\
\text { shop }\end{array}$ & s: (Con & 1 & pok te & $\mathrm{aku}$ & nline \\
\hline
\end{tabular}

Berdasarkan hasil olahan data diketahui bahwa nilai $F_{\text {hitung }}$ sebesar 65,708 dan nilai signifikansi 0,000. Hal ini menunjukkan bahwa $\quad F_{\text {hitung }}>F_{\text {tabel }}$ $(65,708>3,10)$ dan nilai signifikansi $\alpha(0,00<$ $0,05)$ yang berarti dapat disimpulkan bahwa hipotesis ketiga diterima $\left(\mathrm{Ha}_{3}\right)$ yaitu ada pengaruh positif dan signifikan antara online shop dan kelompok teman sebaya terhadap perilaku konsumtif mahasiswa pendidikan ekonomi angkatan 2017 Universitas Negeri Medan.

\section{d. Uji Koefesien Determinasi}

Hasil Uji Koefesien Determinasi $\left(\mathbf{R}^{2}\right)$

Tabel 4 Hasil Uji Koefesien Determinasi $\left(\mathbf{R}^{2}\right)$

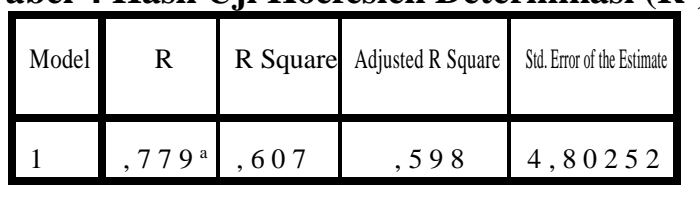

a.Predictors: (Constant), Kelompok Teman Sebaya, Online Shop

b. Dependent Variable: Perilaku Konsumt if Sumber: Pengolahan data menggunakan IBM SPSS 20.0

Berdasarkan tabel di atas bahwa diperoleh nilai $\mathrm{R}$ square sebesar 0,607 yang berarti $0,607 \times 100 \%=60,7 \%$ bahwa variabel bebas mempunyai konstribusi sebesar $60,7 \%$. Hal ini menunjukkan bahwa kemampuan variabel bebas menjelaskan variabel terikat sebesar 60,7\%. Dengan demikian perilaku konsumtif dipengaruhi oleh online shop dan kelompok teman sebaya sebesar $60,7 \%$ dan sisanya $39,3 \%$ dipengaruhi oleh faktor-faktor lain yang di luar penelitian yaitu faktor internal dan faktor eksternal yang mempengaruhi perilaku konsumtif.

\section{Pembahasan Hasil Penelitian}

Dari analisis uji hipotesis yang dilakukan secara parsial menunjukkan hasil pada variabel online shop (X1) nilai $t_{\text {hitung }}>$ $t_{\text {tabel }}$ yaitu 3,835>1,662 dengan nilai signifikansi $\alpha$ sebesar 0,000. Dari penjelasan di atas dapat disimpulkan bahwa ada pengaruh positif dan signifikan online shop terhadap perilaku konsumtif mahasiswa Pendidikan Ekonomi Angkatan 2017 Universitas Negeri Medan. Berdasarkan hasil uji regresi linear berganda sebesar 0,246 yang berarti bahwa setiap terjadi peningkatan online shop sebesar $1 \%$ maka akan menyebabkan peningkatan atau kenaikan online shop 0,246\%. Sehingga dapat disimpulkan bahwa online shop mempengaruhi perilaku konsumtif seseorang.

Menurut Noni (2019) bahwa cara berbelanja pada masa sekarang ini sangatlah dipermudah dengan adanya internet. Sehingga seseorang tidak perlu keluar rumah untuk melakukan pembelian atau mencari baju yang diinginkan akan tetapi cukup untuk melihat di internet. Kemudian Kotler (2007) mengatakan 
bahwa online shop telah menjadi salah satu bentuk pemasaran interaktif yang telah menjadi trend berbelanja dikalangan masyarakat dewasa ini. Membeli kebutuhan barang dan jasa melalui internet sudah menjadi rutinitas konsumen saat ini.

Selanjutnya untuk variabel Kelompok Teman Sebaya berdasarkan hasil penelitian membuktikan bahwa ada pengaruh positif dan signifikan secara parsial variabel kelompok teman sebaya (X2) terhadap perilaku konsumtif diperoleh nilai 10,544>1,662 dan signifikansi $<0,05 \quad(0,000<0,05)$. Sehingga dapat disimpulkan bahwa ada pengaruh positif dan signifikan pada kelompok teman sebaya terhadap perilaku konsumtif.

Berdasarkan uji hipotesis secara simultan (uji F) dapat diketahui bahwa $F_{\text {hitung }}$ sebesar 65,708 sedangkan $F_{\text {tabel }}$ 3,10 maka $\mathrm{F}_{\text {hitung }}>\mathrm{F}_{\text {tabel }}$ dan nilai signifikansi penelitian 0,000 maka $0,000<0,05$. Dengan demikian hipotesis diterima, sehingga dapat disimpulkan bahwa ada pengaruh postif dan signifikan secara simultan online shop dan kelompok teman sebaya terhadap perilaku konsumtif mahasiswa pendidikan ekonomi angkatan 2017.

Nilai koefisien determinasi ( $R$ Square) dalam penelitian ini adalah $R$ Square sebesar 0,607 . Besarnya nilai koefisien 0,607 sama dengan $60,7 \%$. Nilai tersebut bahwa sebesar $60,7 \%$. Hal ini menunjukkan bahwa kemampuan variabel bebas menjelaskan variabel terikat sebesar $60,7 \%$ dan sisanya $39,3 \%$ dipengaruhi oleh faktor-faktor yang mempengaruhi oleh faktor-faktor lain yang diluar penelitian yaitu faktor eksternal dan internal yang mempengaruhi perilaku konsumtif.

\section{KESIMPULAN}

Variabel online shop memiliki pengaruh positif dan signifikan terhadap perilaku konsumtif mahasiswa pendidikan ekonomi angkatan 2017 Universitas Negeri Medan. Hal ini dapat dilihat dari hasil uji t yang menunjukkan nilai thitung sebesar 3,835 dan taraf siginikan $\alpha=0,000<0,05$

Variabel kelompok teman sebaya memiliki pengaruh positif dan signifikan terhadap perilaku konsumtif mahasiswa pendidikan ekonomi angkatan 2017. Hal ini dapat dilihat dari hasil uji t yang menunjukkan nilai $t_{\text {hitung }} 10,544$ dan taraf signifikan $\alpha=0,000$
$<0,05$

Online Shop dan Kelompok Teman Sebaya memiliki pengaruh positif dan signifikan terhadap perilaku konsumtif mahasiswa pendidikan ekonomi angkatan 2017. Hal ini dapat dilihat dari hasil uji $\mathrm{F}$ yang menunjukkan nilai $\mathrm{f}_{\text {hitung }}$ sebesar 65,708 sedangkan $\mathrm{f}_{\text {tabel }} 3,10$ dengan taraf signifikansi $\alpha=0,000<0,05$

\section{REFERENSI}

Desmita (2005). Psikologi PerkembanganI. Bandung. Remaja Rosdakarya

Kotler, Phlip, Lane Keller. 2012. Manajemen Pemasaran Edisi 12. Jakarta : Erlangga

Novandi \& M. Djazari. 2011. "Pengaruh Motivasi Belajar dan Lingkungan Teman Sebaya Terhadap Prestasi Belajar Akuntansi Keuangan Siswa Kelas XIAk SMK Negeri 7 Yogyakarta Tahun Ajaran 2011/2012”. Kajian Pendidikan Akuntansi Indonesia, Universitas Negeri Yogyakarta. Hal : 1-20.

Rozaini Noni.2019.Pengaruh Mata Kuliah Ekonomi Syariah dan Uang Saku Terhadap Perilaku Konsumtif Mahasiswa Pendidikan Ekonomi Angkatan 2016 Universitas Negeri Medan.

Sari, Chacha Andira. 2015. Perilaku Berbelanja Online di Kalangan Mahasiswi Antropologi Universitas Airlangga. AntrounairdotNet Vol.4 No.2

Slamet Santoso.2009. Dinamika Kelompok. Jakarta : Bumi Aksara.

Sumartono. (2012). Terperangkap dalam Iklan:Meneropong Imbas Pesan Iklan Televisi.Bandung : PT. Alfabetia

Taryadi. 2007. Konsumerisme dan Bahaya Jajan di Sekolah.

Wahyudi. 2013. Tinjauan tentang perilaku konsumtif remaja pengunjung Mall Samarinda Central Plaza. eJournal Sosiologi, 1 (4), 26-36

Yusuf, Syamsu LN. 2009. Psikologi Perkembangan Anak dan Remaja. Bandung: PTRemaja Rosdakarya 